\title{
JAVANESE-MATARAMAN MUSLIM OBEDIENCE TOWARDS RELIGIOUS AND STATE LEADERS IN PERFORMING FRIDAY PRAYERS DURING THE COVID- 19 PANDEMIC
}

\author{
Agus Machfud Fauzi \\ Universitas Negeri Surabaya, Indonesia \\ E-mail: agusmfauzi@unesa.ac.id
}

Novi Fitia Maliha

Institut Agama Islam Negeri Ponorogo, Indonesia

E-mail: fitiamaliha@gmail.com

\section{Mustofa}

National Dong Hwa University, Taiwan Republic of China E-mail:810888111@gms.ndhu.edu.tw

\begin{abstract}
The Javanese-Mataraman Muslims have an ambiguous attitude in responding to government policies and religious leaders in carrying out Friday prayers during the early phase of COVID-19 pandemic, symbolically obeying not to do it. However, in reality, they still carry out Friday prayers. This article aims to find out the attitude of community in making decisions on Friday prayers. They usually have an accommodative attitude in responding to the pros and cons of life problems. This article uses mixed methods with a snowball sampling technique to make it easier to find out the community's attitudes using the dramaturgy approach since it had information about the informants' front stage and backstage. The results of this study explain that they have obedience in the front stage. In contrast to the backstage, they perform Friday prayers even though the state and religion prohibit it. The dramaturgy is related to the religious understanding of the Javanese-Mataraman community, hampered by the rigid interpretation of the fiqh of worship, not to the knowledge of maqasid alshari'ah.
\end{abstract}


Keywords: Javanese-Mataraman Muslims; obedience; COVID-19.

\section{Introduction}

At the time of the COVID-19 pandemic in Indonesia today, the Indonesian Ulama Council (MUI) issued a fatwa No. 14 of 2020 that Friday prayers should be replaced with Zuhr prayers held in their respective homes, either alone or in congregation with family. The fatwa is in line with government policies to combat the spread of the COVID-19 pandemic. Furthermore, two mainstream religious organizations in Indonesia, namely Nahdlatul Ulama (NU, based on the decision of Lembaga Bahsul Masail [LBM] NU on March 19, 2020) and Muhammadiyah (based on the Maklumat No. 3/I.0/B/2020), have the same decision as MUI does. Therefore, there is no difference in religious understanding in terms of substitutes for Friday prayers. ${ }^{1}$

However, the MUI fatwa and government policies remain problematic in the religious life of the Javanese-Mataraman Muslim community. They conceptually follow the fatwa and the government policies, but practically they heed them. They did not show criticism of the fatwa and its procedures. In fact, they continued to perform Friday prayers in mosques. This phenomenon is unique and different from other groups' attitudes that both conceptually and practically reject the MUI fatwa and the government policies regarding the abolition of the Friday prayers. Such an ambiguous attitude of the Javanese-Mataraman Muslim is necessary to explain as a form of the attitude of Muslims towards the MUI fatwa and government policies related to the COVID-19 pandemic.

Apart from the ambiguous attitude, the Javanese-Mataraman people were chosen to be the subject of the research since they inherit the Javanese traditions and culture, even to politics and entrepreneurship. ${ }^{2}$ Java is the richest island in terms of traditions

\footnotetext{
1 Arifinsyah et al., "Pesantren Religious Paradigm;" Andini Nurrahmah Dewi and Agus Machfud Fauzi, "Peran Tokoh Agama dalam Meningkatkan Religiusitas Warga Desa Giri, Kabupaten Gresik di Masa Pandemi COVID-19," Tajdid: Majalah Ilmu Pengetahuan dan Pemikiran Keagamaan, Vol. 24, No. 1 (2021), 65-73.

2 Wawan Sobari, "The Practice of Political Entrepreneurship in a Rural Javanese Village," JSP: Jurnal Ilmu Sosial dan Ilmu Politik, Vol. 23, No. 1 (2019), 30.
} 
and cultural treasures compared to others in Indonesia. JavaneseMataraman refers to one of the community groups in Java, which inherits Javanese characteristics of the Solo court. They carry out an accommodative life pattern rather than the confrontative one. In terms of language, they also speak 'more Javanese' than other communities. Meanwhile, a shift occurred in giving one's name as identity, from the Javanese-caste based to the Arabic-non-caste based names. ${ }^{3}$

This article seeks to answer some crucial questions extracted from the questionnaire: What is the Javanese-Mataraman Muslim dramaturgy in responding to the MUI fatwa and the decision made by NU and Muhammadiyah regarding Friday prayers during the COVID-19 pandemic? What are their dramaturgical answers about the COVID-19 pandemic to the person they listened to the most?

This study employs a mixture of quantitative and qualitative methods ${ }^{4}$ by taking informants from the citizens of the JavaMataraman regencies and cities, including Madiun, Ngawi, Magetan, Pacitan, Ponorogo, Trenggalek, Tulungagung, Blitar, Kediri, and Nganjuk. Those regencies and cities were formerly part of the royal government of Mataram so that their traditions and cultures have similarities. To further explore and find out the profile of research subjects, this article uses the Erving Goffman's Dramaturgy approach. ${ }^{5}$

Dramaturgy is an approach to interpret daily human life, which is like playing a drama on stage. The stage consists of the front stage and backstage. As a drama, what happens on the front stage is often not the same as backstage. Based on this approach, the conceptual acceptance of the Javanese-Mataraman Muslims towards the MUI fatwa and the government's policies not to perform Friday prayers during the COVID-19 pandemic is the

3 Askuri and Joel Corneal Kuipers, "The politics of Arabic Naming and Islamization in Java: Processes of Hybridization and Purification," Al-jamiah: Journal of Islamic Studies, Vol. 56, No. 1 (2018), 59-94.

${ }^{4}$ Stefan Cojocaru, "Challenges in Using Mix Methods in Evaluation," Postmodern Openings (2010), retrieved from < https://www.ceeol.com/sear ch/articledetail $P i d=105839>$.

5 Vita Amelia and Triono Dul Hakim, "Librarian Services at Unilak's Main Library Environment: A Dramaturgi Approach," IOP Conference Series Earth and Environmental Science 469, retrieved from <https://iopscience.iop.org/ article/10.1088/1755-1315/469/1/012044/meta $>$. 
construction of the front stage, and the fact that they continue to perform Friday prayers in mosques is the reality of the backstage.

In extracting information, this article uses snowball sampling. This method is more likely to be used to carry out research during the COVID-19 pandemic to get information from informants. In addition, this method can represent all Javanese-Mataraman Muslims because, in the process, it does not need to select informants strictly, but distribute research questionnaires in the Google Forms through social media to informants, without any coercion in answering questions.

There are 276 respondents who gave answers to the questionnaires. In addition, the authors interviewed those who were considered crucial to provide information about the obedience of Javanese-Mataraman Muslims on Friday prayers and held a small in-depth discussion attended by 30 people to deepen the results of study. Therefore, the analysis was based on quantitative data collected from 276 respondents as the initial material for research analysis. To deepen the analysis, the qualitative data then uses various information from in-depth discussion processes.

\section{The Obedience of the Javanese-Mataraman Muslims}

The phenomenon of a Muslim's obedience does not always match the conception of obedience as religious doctrine. The COVID-19 pandemic has changed one's perception of obedience in worship. In the context of the pandemic in Indonesia, obedience in carrying out worship has seemingly been separated from, and even confronted to, obedience in carrying out the orders of leaders, both religious and state leaders. This has become the subject of endless debate because, in the Qur'ān (al-Nisā' [4]: 59), it is stated that every Muslim must obey Allah, His Messenger, and the leaders of the state (ulu al-amr).

The doctrine of obedience needs to adjust one's condition in responding to a command. One's relationship with God, religious leaders, and state leaders does not come suddenly but requires an explanation of an event. An unjust government does not need to be obeyed, but must be fought against a revolutionary movement. ${ }^{6}$

6 Sudarnoto Abdul Hakim, "Islam and Government: An Analytical Review on Khumayni’s Kashf al-Asrār and Wilāyat al-Fāqih," Indonesian Journal of Islam and 
Given that the government in Indonesia is running well and fairly, such a movement does not need to be actualized. Through the state ideology of Pancasila, the Indonesian government can even run in line to the methodological framework of maqașid al-sharí'ah developed by al-Juwaynī, 'Izz al-Dīn b. 'Abd al-Salām, Abū Ishạāq al-Shātịīī, and al-Ṭāhir b. 'Ashūr.'

In Indonesian history, the Muslim community shows the dynamics of obedience to the orders of the state and religion at the same time. This is a good precedent for the community in the future as it becomes part of Islamic doctrine. In addition, according to the prominent Muslim Scholar Nurcholish Madjid, obeying the Indonesian government is better for the Muslim community than 'Islamizing' Indonesia, as recently echoed. Therefore, Madjid opposes the making of Indonesia as an Islamic state and, at the same time, refuses to make it a secular one. ${ }^{8}$

Sayyid Qutb explains the concept of obedience in his commentary book, Fi Zilal al-Qur'an, stating that Islam as religion cannot exist if there is no Muslim obedience to shari'ah rooted in the values of monotheism (tawhid). ${ }^{9}$ Such obedience would not make a Muslim radical due to a wrong understanding of religious

Muslim Societies, Vol. 8, No. 1 (2018), 147-171; Several verses in the Qur'ān forbid a person to obey leaders who lead astray (al-Ahyāb [33]: 34), disbelievers (al-Furqān [25]: 52), hypocrites (al-Aḥzāb [33]: 48), deniers of the Qur'ān (alQalam [68]: 8), and every mean swearer (al-Qalam [68]: 10). Therefore, as a leader in carrying out his duties and obligations involves desires and intentions. See Allendia Traviana et al., "Pengaruh Kepemimpinan Diri, Lingkungan Kerja terhadap Pengembangan Karir Penerbang di Indonesia dengan Motivasi sebagai Variabel Intervening," Coopetition: Jurnal Ilmiah Manajemen, Vol. 12, No. 2 (2021), 181-188.

7 Elviandari et al., "The Formulation of Welfare State: The Perspective of Maqāṣid al-Sharī'ah," Indonesian Journal of Islam and Muslim Societies, Vol. 8, No. 1 (2018), 117-146.

8 Ahmad Ali Nurdin, "Revisiting discourse on Islam and state relation in Indonesia: The view of Soekarno, Natsir and Nurcholish Madjid," Indonesian Journal of Islam and Muslim Societies, Vol. 6, No. 1 (2016), 63-92; Muzayyin Ahyar and Alfitri, "Aksi Bela Islam: Islamic Clicktivism and the New Authority of Religious Propaganda in the Millennial Age Indonesia," Indonesian Journal of Islam and Muslim Societies, Vol. 9, No. 1 (2019), 1-29.

9 Sayyid Quthb, Tafsir Fi Zhilalil-Qur'an: Di Bawah Naungan Al-Qur'an, Vol. 1, retrieved from <https://books.google.com/books?hl=en\&lr=\&id=SGLbgwo GkoEC\&oi=fnd\&pg $=$ PA $5 \& d q=$ tafsir + fi + dzilalil + qurnan + taat\&ots $={ }_{\mathrm{s}} \mathrm{C} 8 \mathrm{zNk} 1$ kuF\&sig=qHtitX4m8fyogMYqxDSNNEqulpE $>$. 
texts. ${ }^{10} \mathrm{~A}$ false sense of the concept will only give birth to a blind obedience. Put the Jihad command as an example, which is always understood as a "must-fight," even though such obedience can be articulated as, among others, intellectual and creativity sharpening. ${ }^{11}$ Admittedly or not, such kind of blind obedience seems to infect some Indonesian Muslims, including some Javanese-Mataraman Muslims, so that they have ambiguous obedience in responding to the orders of state and religious leaders, especially in the context of dealing with COVID-19.

The Javanese-Mataraman Muslims refer to a society that makes Javanese life philosophy a way of life. Islamization made them Muslims who do not break away from Javanese culture in terms of knowledge, belief, and religious practices. ${ }^{12}$ In the community, Islamic and Javanese identities become equal and unseparable, as seen in cultural genealogy, traditional religious teachings, and conceptions of power in the Javanese court. ${ }^{13}$ It should be noted that not all Muslims perfectly perform worship in their daily lives. However, as long as they do accept and embrace Islamic way of life and of conduct, they will still be considered as Muslims. ${ }^{14}$

The Javanese-Mataraman Muslim community has a different religious life from the Arab-Muslim community in the Middle East. Although the clothes of the two have something in common, namely both covering the genitals, the clothes are very different in style and form. In addition, their daily lives are also different because both are originated from separate roots of tradition and culture. The only thing that makes them truly the same is implementing the pillars of Islam and that of faith. However, the life of pluralism has been built in the Javanese people life since

10 Siti Komariah, "Radicalization: The Misconception of Religious Practices in Diversity," The Journal of Society and Media, Vol. 4, No. 1 (2020), 49-65.

11 Arifinsyah et al., "Pesantren Religious Paradigm: Aqeedah, Plurality, and Jihad," The Journal of Society and Media, Vol. 3, No. 2 (2019), 278-298.

12 Haedar Nashir and Mutohharun Jinan, "Re-Islamisation: The Conversion of Subculture from Abangan into Santri in Surakarta," Indonesian Journal of Islam and Muslim Societies, Vol. 8, No. 1 (2018), 1-28.

13 Sulistiyono Susilo and Ibnu Syato, "Common Identity Framework of Cultural Knowledge and Practices of Javanese Islam," Indonesian Journal of Islam and Muslim Societies, Vol. 6, No. 2 (2016), 161-184.

14 Medhy Aginta Hidayat, "Ibadat, The Body and Identity: Islamic Rituals and The Construction of Muslim Identity," The Journal of Society and Media, Vol. 1, No. 2 (2017), 1-18. 
they were experiencing the Hindu-Buddhist times. ${ }^{15}$ Thus, progress can run smoothly in the life of the Javanese people because there is no identity politics in carrying out their collective life. ${ }^{16}$

The Javanese-Mataraman Muslims include an obedient group in carrying out Islamic religious orders, as they have normative piety. ${ }^{17}$ Even though they are not of Middle Eastern or Arab descent, they accept the teachings of Islam with joy. This cannot be separated from the role of previous Islamic preachers in Java who have attempted to fuse Islamic teachings with Javanese culture. $^{18}$

Like the Javanese Muslims in general, the Javanese-Mataraman Muslims lead an Islamic life based on the understanding of Islam Nusantara for those who have closeness to traditional Islam, ${ }^{19}$ and of Islam Berkemajuan for those who are oriented towards modern Islam. ${ }^{20}$ Both two approaches of understanding, despite all their differences, make the Friday prayers commandment an obligation that cannot be played with. The Javanese-Mataraman Muslim therefore confirmed that Friday prayers are an obligation for every Muslim male. They realize that the obligation is included in their doctrine so that anyone who does not practice will be sinful. Therefore, they make such worship the construction of sacred rituals and as the identity of a Muslim. ${ }^{21}$

15 Al Makin, “Unearthing Nusantara's Concept of Religious Pluralism: Harmonization and Syncretism in Hindu-Buddhist and Islamic Classical Texts," Al-Jamiah: Journal of Islamic Studies, Vol. 54, No. 1 (2016), 1-30.

16 Agus Machfud Fauzi et al., "Maintaining Identity Political Culture in Indonesia," Journal of Physics (2018), available at <https://iopscience. iop.org/article/10.1088/1742-6596/953/1/012185/meta $>$.

${ }_{17}$ Mark R. Woodward, Islam Jawa; Kesaleban Normatif versus Kebatinan (Yogyakarta: LKiS, 2004).

18 Yudi Latif, Mata Air Keteladanan: Pancasila dalam Perbuatan (Bandung: Mizan, 2014).

19 Abdurrohman Kasdi, "Reconstruction of Fiqh Nusantara: Developing the Ijtihad Methodology in Formulating Fiqh from Indonesian Perspective," Qudus International Journal of Islamic Studies, Vol. 7, No. 2 (2019), 239-266.

20 Niki Alma Febriana Fauzi and Ayub, "Fikih Informasi: Muhammadiyah's Perspective on Guidance in Using Social Media," Indonesian Journal of Islam and Muslim Societies, Vol. 9, No. 2 (2019), 267-293; Saiful Mujani, "Explaining Religio-political Tolerance among Muslims: Evidence from Indonesia," Studia Islamika, Vol. 26, No. 2 (2019), 319-351.

${ }^{21}$ Hidayat, "Ibadat, the Body," 1-17. 
Friday prayers are the religious commandments for every male Muslim, held in mosque once a week. Therefore, every male Muslim is obliged to perform the Friday prayers which are begun with sermon, in every Friday at noon, as a substitute for the Zuhr prayerss. Those who do not perform Friday prayers are categorized as a wicked person, even an infidel, except for those subject to such 'udhr shari as being sick, stricken by a disaster, on a journey that is not possible to perform prayers, and so on.

The current problem of COVID-19 pandemic brings Muslims into a dilemma. Worship and all other religious activities stopped. ${ }^{22}$ Thus, religious and state orders came and contradicted each other in responding to the COVID-19 pandemic. Obeying religious orders is as important as following state orders. However, the two orders seemed unable to run simultaneously; to run one means to abandon the other. This is a challenge for a Muslim. The challenge becomes even more difficult, especially for those whose religious understanding is not good enough. Such a condition has been experienced by Muslims, among others, in carrying out Friday prayers during the pandemic. ${ }^{23}$

\section{The Dramaturgical Response to the Fatwa on Friday Prayers during the Pandemic}

The Indonesian Ulama Council (MUI) is a religious authority institution that bridges the interests of various religious understandings in Indonesia. It became a gathering place for scholars from various Islamic organizations, including NU, Muhammadiyah, Persis, Al-Irsyad, etc. MUI also presents various fatwas for Indonesia's inter and intrareligious tolerance. ${ }^{24}$

Although MUI is a religious institution that is structurally under the auspices of the Indonesian government, it does not

\footnotetext{
22 Naufalul Ihya Ulumuddin and Agus Machfud Fauzi, "Solidaritas Sosial Komunitas Sholawat Syekher Mania Labang dalam Membangun Eksistensi di Masa Pandemi," Sosiobumaniora: Jurnal Ilmiah Ilmu Sosial dan Humaniora, Vol. 7, No. 2 (2021), 20-28.

23 Ahmad Saefulloh et al., "COVID-19 Prevention (Study of COVID-19 Protocol and Relationship of Wudhu)," The Journal of Society and Media, Vol. 5, No. 1 (2021), 99-118.

24 Syafiq Hasyim, "Religious Pluralism Revisited: Discursive Patterns of the Ulama Fatwa in Indonesia and Malaysia," Studia Islamika, Vol. 26, No. 3 (2019), 475-509.
} 
work for the government. ${ }^{25}$ The direct impact of the MUI's existence on the community is not so apparent because NU, Muhammadiyah, and others have guarded the religious understanding and practice of the community. MUI does not work to provide religious understanding to the public under specific methods (manhaj), for example, the Indonesian government's method, because MUI is not in the capacity to become a new religious organization.

The Javanese-Mataraman Javanese Muslims approved the MUI fatwa No. 14 of 2020 concerning the permission for a person to leave Friday prayers for dealing with the COVID-19 pandemic. This can be seen from the response of the 276 JavaneseMataraman Muslim respondents, most of whom agree with the MUI fatwa. However, the percentage of their disagreement is tiny and does not have a significant effect. This can be seen in the following figure:

$$
1,522,000,+5,700,000+500
$$

Figure 1. Responses to the fatwa of MUI No. 14 of 2020 regarding the permission of leaving Friday prayers.

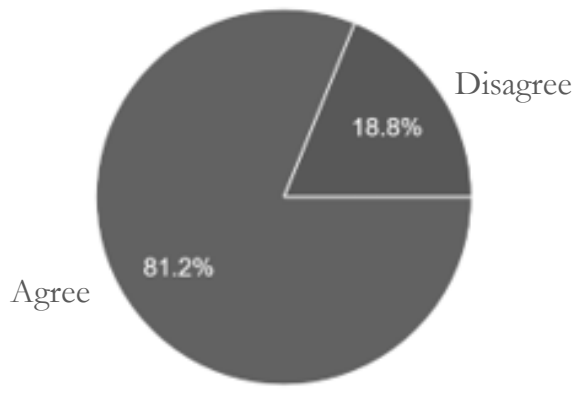

In fact, the answer does not mean that all Javanese Muslims in Matraman do not perform Friday prayers. Some of them continue to perform Friday prayers at a mosque, and some of them replace it with Zuhr prayers at home. The answer departs from a theoretical understanding, but in practice, they cannot deny their

\footnotetext{
${ }^{25}$ La Jamaa, "Fatwas of the Indonesian Council of Ulama and Its Contributions to the Development of Contemporary Islamic Law in Indonesia," Indonesian Journal of Islam and Muslim Societies, Vol. 8, No. 1 (2018), 29-56.
} 
conscience or habit of carrying out the Friday prayers's commandment.

The position of the MUI is not as close as that of religious organizations that often come into direct contact with the community, providing instructions and directions on how to worship and organize. Javanese-Matraman Muslim's obedience to MUI is none other than because its fatwa can rationally be accepted as an anticipation of the COVID-19 pandemic. The community admits that the threat of the COVID-19 destroys social life, including religious activities.

Most of Javanese-Mataraman Muslims are the followers of such organizations as NU and Muhammadiyah. When asked about the decisions of the two organizations, represented by the Maklumat No. 3/I.0/B/2020 and the decision of LBM NU issued on March 19, 2020, they stated that they respect the decision. For them, the decision is very beneficial for human life.

The community's response to the decisions is relatively the same as their response to the MUI fatwa. Thus, although the percentages are different in detail, the decisions of the two organizations have similarities in general.

Figure 2. Responses to the decisions of NU and Muhammadiyah on the performing Zuhr prayers instead of Jum'at prayers.

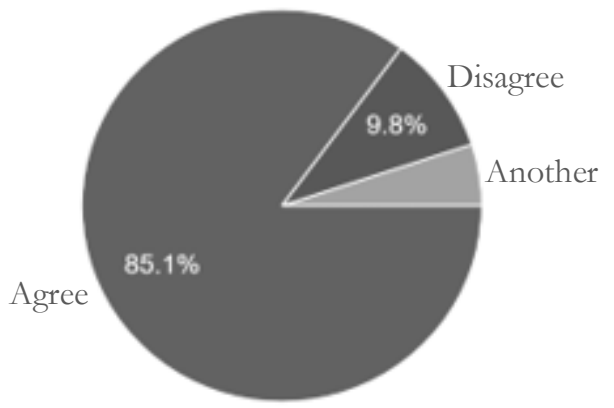

The Javanese-Mataraman Muslims have a firm attitude in responding to the MUI fatwa and the religious organizations' decisions regarding replacing Friday prayers in mosques with Zuhr prayers at home. They agreed to the fatwa and the decision without coercion. However, the agreement does not necessarily express their actions in practice. 
In fact, the obedience of Javanese-Mataraman Muslims to the MUI fatwa and the decisions of religious organizations do not always go according to reality. For example, only some of them perform the Zuhr prayers at their respective homes, while some others, which is not a few in number, still perform Friday prayers in the mosque. However, this does not mean that they refuse but show an ambiguous response. In theory, they agree with the fatwa and decision, but they do not do what they have decided to in practice.

On Friday of this research week, some areas of Mataraman were labelled as red zones (Magetan, Tulungagung, Nganjuk, Kediri City and Kediri Regency), and some were still in the yellow zones (Ngawi, Ponorogo, Pacitan, Trenggalek). What happened was that the most of respondents did not perform Friday prayers, as many as $58 \%$, while $40.6 \%$ performed Friday prayers, and $1.4 \%$ did not provide an explanation.

The figure of $40.6 \%$ who still go to the mosque and congregate to perform Friday prayers is a relatively large number, considering fatwas and the ban on Friday prayers in mosques came from many religious authorities such as MUI, NU, and Muhammadiyah. Therefore, a big question arises about whose fatwa, decision, or recommendation they follow, which still orders Friday prayers in mosques.

To further explore the ambiguous attitudes of the community, one of the crucial questions posed to them was their attitude towards the MUI fatwa. Most of them, which was about a quarter of the respondents, stated that they obeyed the MUI fatwa, and a small number had different opinions and were not willing to disclose, as illustrated in the following figure:

Figure 3. How a Muslim should respond to the MUI Fatwa

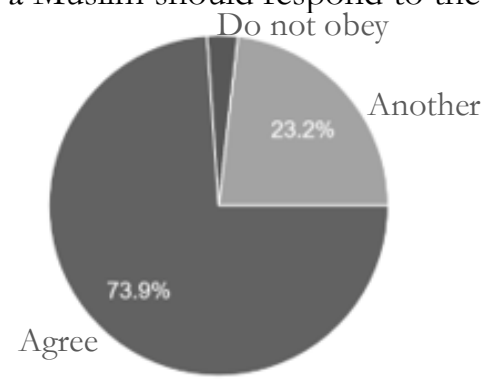


The same attitude was shown by the Javanese-Mataraman Muslims towards the instructions of NU and Muhammadiyah regarding the COVID-19 pandemic. Most of Javanese-Mataraman Muslims are members of NU and Muhammadiyah. As members, they should obey any instructions or decisions issued by the two organizations. However, their attitudes towards the instructions or decisions of the two organizations varied. Most of them show obedience, while only a minority express disobedience. Their response can be seen in the following figure:

Figure 4. How should a member of NU or Muhammadiyah respond to the instructions from the two organizations

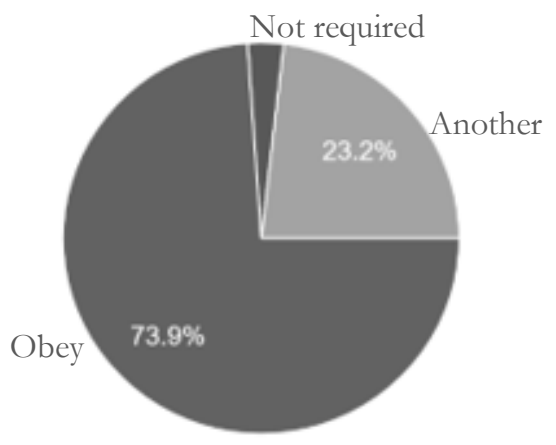

Based on the figure, Javanese-Mataraman Muslims have two typologies in terms of attitude towards the instructions of religious and state authorities regarding the prohibition of performing Friday prayers in mosques. Some have replaced Friday prayers with Zuhr prayers in congregation at their respective homes, while others are still doing the opposite, although they have also approved the rules for prohibiting Friday prayers in mosques during the COVID-19 pandemic.

They cannot have one view in carrying out the instructions of MUI, NU, or Muhammadiyah. This fact strengthens the view that certain parties cannot hinder a person's independence in carrying out worship. Religious life is a very personal life, which resides only in the depths of each individual's heart.

MUI, with its fatwa, cannot intervene in the community to stop the spirit of carrying out Friday prayers. The religious doctrine that Friday prayers are obligatory for men then must be fought for. When asked for their opinion about whether they agree 
and will obey or not, the MUI fatwa, several facts can be extracted from their attitude. Firstly, they feel guilty if they do not perform Friday prayers. This happens to the Javanese-Mataraman Muslim community, who understands religious teachings just in blackwhite. The orders are considered unable to be deflected by 'udhr or other reasons. They emphasize the threat of sinful even infidel to any Muslim who does not do so.

Secondly, Javanese-Mataraman Muslims feel they are missing Friday prayers if they do not do it. They think that something is missing when they do not carry out "the habit" of Friday prayers. Friday prayers have become a tradition and culture, and therefore it has become a basic necessity. Thus, the problem is no longer about whether or not it is permissible to leave obligations but has become a necessity of life.

Thirdly, they find it very difficult not to attend the mosque for Friday prayers. This happens for those who want to leave Friday prayers but feel uncomfortable when they see people all gathered in the mosque while they pray Zuhr at home. This shows that worship has become an instrument of communication and consolidation of Muslim life. This fact can also be an answer to how humans need other people in their lives.

Like MUI, NU and Muhammadiyah also cannot intervene. The citizens' obedience to the instructions of NU and Muhammadiyah is limited to only words, not to real life. In the case of avoiding the COVID-19 pandemic, the attitude of the Javanese-Mataraman Muslim community is relatively the same as their attitude towards the MUI in the previous discussion.

This phenomenon shows that there is an unlinked understanding between religious elites and society in general about worship. Religious elites with qualified religious knowledge can easily make religious legal products not to perform Friday prayers. This is different from most people who are just knowing a readymade legal product. Of course, people who understand an obligation to carry out religious orders also understand the substance and background of an obligation. The latter can find out how to get out of an order that cannot be done because of the demands of the situation, not of feeling lazy.

Indeed, the religious life constitutes the area of ijtibadiyah to get the best understanding and implementation of a religious theory 
and practice. However, knowledge regarding the performance of Friday prayers have no longer needed reinterpretation because MUI, as the state representative, already has similar Islamic legal products with NU and Muhammadiyah in terms of directing Muslims to pray during the COVID-19 pandemic.

The labelling of red zones for areas infected primarily by COVID-19, and yellow zones for areas whose infected citizens are still in low number, is seen as a simple problem by the JavaneseMataraman Muslim community. Therefore, this assumption triggers them to take a counterproductive attitude toward what was ordered or instructed by the religious and state authorities.

The Javanese philosophy of life, "Enggih-enggih ora kepanggih," occurred in the community's religious practice during the pandemic period. This philosophy of life does not only happen nowadays, but since the colonial era, it has been running in the life of Javanese people. To avoid conflict or differences with other people, the way they do is to accept a case but not to carry it out.

The philosophy of life is ingrained in the lives of Javanese people, including the Javanese-Mataraman Muslims. This philosophy is a form of dramaturgy of Javanese society towards a social phenomenon or fact that does not match their thoughts and desires. Thus, they have the front stage to accept a decision and the backstage not to carry out the decision.

In this case, the front stage for the Javanese-Mataraman Muslims is to accept the MUI fatwa and instructions issued by NU and Muhammadiyah regarding the prohibition of performing Friday prayers in mosques and performing Zuhr prayers in congregation in their respective homes instead of Jum'ah prayers. Therefore, a drama displayed on the front stage is needed so that it is not considered to reject the instructions of those three respected institutions.

On backstage, they continued to perform Friday prayers even though they knew the risk. They still carried out the Friday prayers because they found emotion with the worship. In addition, at the time this research was conducted, they did not feel threatened by COVID-19, perhaps because they had not been directly affected by COVID-19.

The obligation to perform Friday prayers is nothing but a command from God for each individual, including the Javanese- 
Mataraman Muslims. The one who knows the essence of carrying out or ignoring the religious orders is the individual concerned. Therefore, their response can only be seen in the context of the individual, not the public.

\section{Conclusion}

The Javanese-Matraman Muslims practice the teachings of Islam without leaving the traditions and culture that shape their personalities. They obey religious leaders and the state as one of the Islamic doctrines life guidelines, without leaving what they believe so far. Even though religious and state leaders have given orders or instructions about a case, they do not just carry out (taqlīd) them before getting a rational explanation. This has become a kind of local wisdom in the life of the Javanese Mataraman Muslim community. The dramaturgy of religious life occurs because the Javanese-Mataraman Muslims have a spiritual understanding strongly linked to Javanese life and culture, with a philosophy of "enggih-enggih ora kepanggih."

The discussion in this article contributes to the varied and increasingly complex phenomena of Islamic life, and the JavaneseMataraman Muslim is one of them. Furthermore, the phenomenon of the Javanese-Mataraman Muslim enriches the various understanding of religious life, which always goes hand in hand with local wisdom in an area, as they show in how they approve the decisions of many religious organizations and the government's instructions but do not implement them.

\section{Bibliography}

Ahyar, Muzayyin and Alfitri. "Aksi Bela Islam: Islamic Clicktivism and the New Authority of Religious Propaganda in the Millennial Age Indonesia," Indonesian Journal of Islam and Muslim Societies, Vol. 9, No. 1, 2019.

Amelia, Vita and Triono Dul Hakim, "Librarian Services at Unilak's Main Library Environment: A Dramaturgi Approach," IOP Conference Series Earth and Environmental Science 469, retrieved from <https://iopscience.iop.org/ article/10.1088/1755-1315/469/1/012044/meta $>$. 
Arifinsyah et al. "Pesantren Religious Paradigm: Aqeedah, Plurality, and Jihad," The Journal of Society and Media, Vol. 3, No. 2, 2019.

Askuri and Joel Corneal Kuipers. "The politics of Arabic Naming and Islamization in Java: Processes of Hybridization and Purification," Al-Jami'ah: Journal of Islamic Studies, Vol. 56, No. 1, 2018.

Cojocaru, Stefan. "Challenges in Using Mix Methods in Evaluation," Postmodern Openings (2010), retrieved from $<$ https://www.ceeol.com/sear ch/article-detail?id=105839 $>$.

Dewi, Andini Nurrahmah and Agus Machfud Fauzi. "Peran Tokoh Agama dalam Meningkatkan Religiusitas Warga Desa Giri, Kabupaten Gresik di Masa Pandemi COVID-19," Tajdid: Majalab Ilmu Pengetahuan dan Pemikiran Keagamaan, Vol. 24, No. 1, 2021.

Elviandari et al. "The Formulation of Welfare State: The Perspective of Maqāṣid al-Sharī'ah," Indonesian Journal of Islam and Muslim Societies, Vol. 8, No. 1, 2018.

Fauzi, Agus Machfud et al. "Maintaining Identity Political Culture in Indonesia," Journal of Physics (2018), available at $<$ https://iopscience.iop.org/article/10.1088/1742-6596/953/ $1 / 012185 /$ meta $>$.

Fauzi, Niki Alma Febriana and Ayub. "Fikih Informasi: Muhammadiyah's Perspective on Guidance in Using Social Media," Indonesian Journal of Islam and Muslim Societies, Vol. 9, No. 2, 2019.

Hakim, Sudarnoto Abdul. "Islam and Government: An Analytical Review on Khumayni's Kashf al-Asrār and Wilāyat al-Fāqih," Indonesian Journal of Islam and Muslim Societies, Vol. 8, No. 1, 2018.

Hasyim, Syafiq. "Religious Pluralism Revisited: Discursive Patterns of the Ulama Fatwa in Indonesia and Malaysia," Studia Islamika, Vol. 26, No. 3, 2019.

Hidayat, Medhy Aginta. "Ibadat, The Body and Identity: Islamic Rituals and The Construction of Muslim Identity," The Journal of Society and Media, Vol. 1, No. 2, 2017.

Jamaa, La. "Fatwas of the Indonesian Council of Ulama and Its Contributions to the Development of Contemporary Islamic 
Law in Indonesia," Indonesian Journal of Islam and Muslim Societies, Vol. 8, No. 1, 2018.

Kasdi, Abdurrohman. "Reconstruction of Fiqh Nusantara: Developing the Ijtihad Methodology in Formulating Fiqh from Indonesian Perspective," Qudus International Journal of Islamic Studies, Vol. 7, No. 2, 2019.

Komariah, Siti. "Radicalization: The Misconception of Religious

Practices in Diversity," The Journal of Society and Media, Vol. 4, No. 1, 2020.

Latif, Yudi. Mata Air Keteladanan: Pancasila dalam Perbuatan. Bandung: Mizan, 2014.

Makin, Al. "Unearthing Nusantara's Concept of Religious Pluralism: Harmonization and Syncretism in Hindu-Buddhist and Islamic Classical Texts," Al-Jami'ah: Journal of Islamic Studies, Vol. 54, No. 1, 2016.

Mujani, Saiful. "Explaining Religio-political Tolerance among Muslims: Evidence from Indonesia," Studia Islamika, Vol. 26, No. 2, 2019.

Nashir, Haedar and Mutohharun Jinan. "Re-Islamisation: The Conversion of Subculture from Abangan into Santri in Surakarta," Indonesian Journal of Islam and Muslim Societies, Vol. 8, No. 1, 2018.

Nurdin, Ahmad Ali. "Revisiting discourse on Islam and state relation in Indonesia: The view of Soekarno, Natsir and Nurcholish Madjid," Indonesian Journal of Islam and Muslim Societies, Vol. 6, No. 1, 2016.

Quthb, Sayyid. Tafsir Fi Zhilalil-Qur'an: Di Bawah Naungan AlQur'an, Vol. 1, retrieved from < https://books.google.com/ books?hl=en\&lr=\&id=SGLbgwoGkoEC\&oi=fnd\&pg=PA5 $\underline{\mathrm{ddq}}=\mathrm{tafsir}+\mathrm{fi}+\mathrm{dzilalil}+$ qurnan + taat\&ots $=\mathrm{s} C 8 \mathrm{zNk} 1 \mathrm{kuF} \&$ sig $=$ qHtitX4m8fyogMYqxDSNNEqulpE $>$.

Saefulloh, Ahmad et al. "COVID-19 Prevention (Study of COVID-19 Protocol and Relationship of Wudhu)," The Journal of Society and Media, Vol. 5, No. 1, 2021.

Sobari, Wawan. "The Practice of Political Entrepreneurship in a Rural Javanese Village," JSP: Jurnal Ilmu Sosial dan Ilmu Politik, Vol. 23, No. 1, 2019.

Susilo, Sulistiyono and Ibnu Syato. "Common Identity Framework of Cultural Knowledge and Practices of Javanese Islam," 
Indonesian Journal of Islam and Muslim Societies, Vol. 6, No. 2, 2016.

Traviana, Allendia et al. "Pengaruh Kepemimpinan Diri, Lingkungan Kerja terhadap Pengembangan Karir Penerbang di Indonesia dengan Motivasi sebagai Variabel Intervening," Coopetition: Jurnal Imiah Manajemen, Vol. 12, No. 2, 2021.

Ulumuddin, Naufalul Ihya and Agus Machfud Fauzi. "Solidaritas Sosial Komunitas Sholawat Syekher Mania Labang dalam Membangun Eksistensi di Masa Pandemi," Sosiobumaniora: Jurnal Ilmiah Ilmu Sosial dan Humaniora, Vol. 7, No. 2, 2021.

Woodward, Mark R. Islam Jawa; Kesalehan Normatif versus Kebatinan. Yogyakarta: LKiS, 2004. 